Prepared in cooperation with Pendleton County, Kentucky, and the U.S. Army Corps of Engineers-Louisville District

\title{
Flood-Inundation Map Library for the Licking River and South Fork Licking River near Falmouth, Kentucky
}

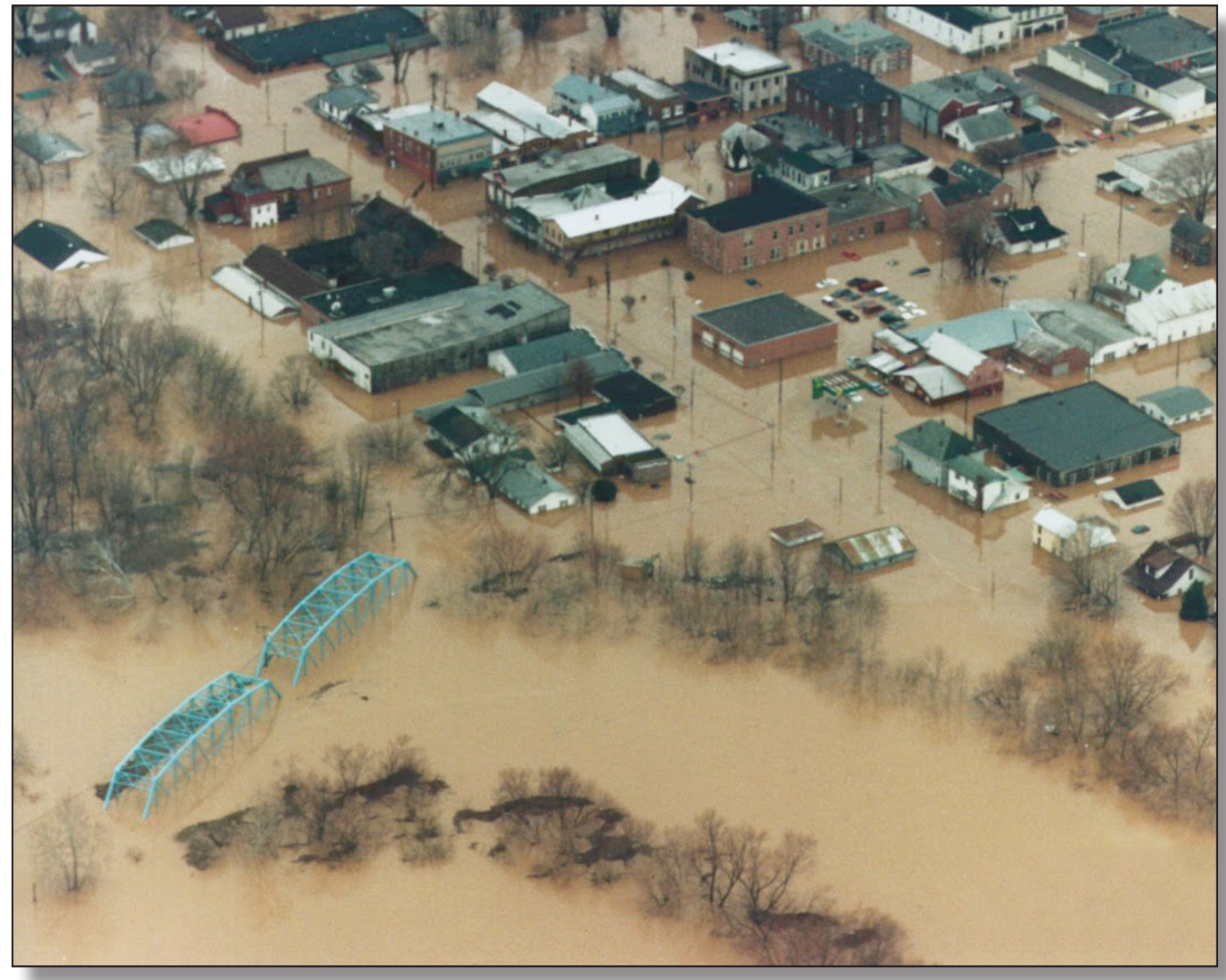

Scientific Investigations Report 2016-5108

U.S. Department of the Interior

U.S. Geological Survey 
Cover. Flooding of Falmouth, Ky., after the Licking River overflowed its banks. Photograph courtesy of the Kenton County Public Library. 


\section{Flood-Inundation Map Library for the Licking River and South Fork Licking River near Falmouth, Kentucky}

By Jeremiah G. Lant

Prepared in cooperation with Pendleton County, Kentucky, and the U.S. Army Corps of Engineers-Louisville District

Scientific Investigations Report 2016-5108 


\section{U.S. Department of the Interior SALLY JEWELL, Secretary}

\section{U.S. Geological Survey Suzette M. Kimball, Director}

\section{U.S. Geological Survey, Reston, Virginia: 2016}

For more information on the USGS - the Federal source for science about the Earth, its natural and living resources, natural hazards, and the environment—visit http://www.usgs.gov or call 1-888-ASK-USGS.

For an overview of USGS information products, including maps, imagery, and publications, visit http://store.usgs.gov.

Any use of trade, firm, or product names is for descriptive purposes only and does not imply endorsement by the U.S. Government.

Although this information product, for the most part, is in the public domain, it also may contain copyrighted materials as noted in the text. Permission to reproduce copyrighted items must be secured from the copyright owner.

Suggested citation:

Lant, J.G., 2016, Flood-Inundation Map Library for the Licking River and South Fork Licking River near Falmouth, Kentucky: U.S. Geological Survey Scientific Investigations Report 2016-5108, 13 p., http://dx.doi.org/10.3133/sir20165108.

ISSN 2328-0328 (online) 


\section{Acknowledgments}

The author wishes to thank the local, State, and Federal agencies that have cooperated in and (or) funded the operation and maintenance of the streamgage used for this study, especially Pendleton County. Special thanks are given to the previous Judge-Executive of Pendleton County, The Honorable Henry Bertram (1999-2014); the current Judge-Executive, The Honorable David Fields of Pendleton County; and Mike Moore the Director of Pendleton County Emergency Management for their cooperation in this study; and to the U.S. Army Corps of EngineersLouisville District and the National Weather Service for their continued support of the U.S. Geological Survey flood-inundation mapping initiative. 



\section{Contents}

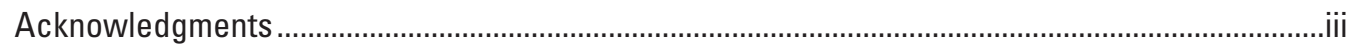

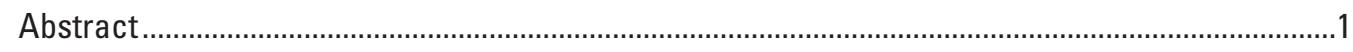

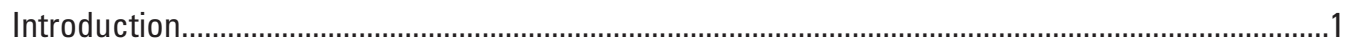

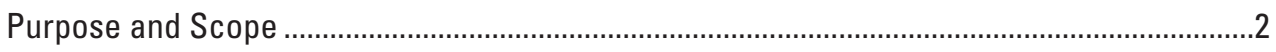

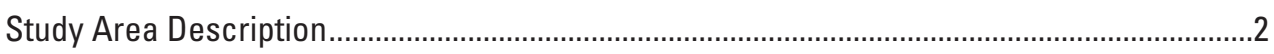

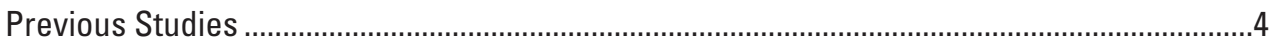

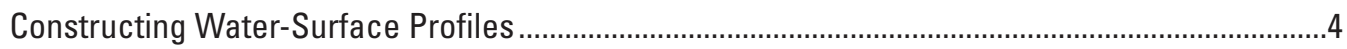

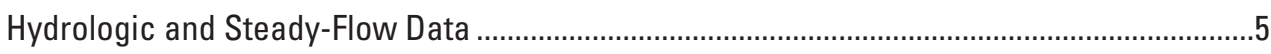

Topographic and Bathymetric Data ...................................................................................

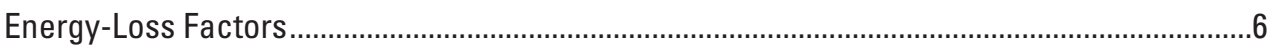

Model Calibration and Performance ..................................................................................

Development of Water-Surface Profiles..................................................................................

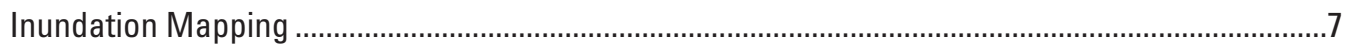

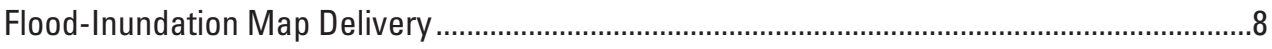

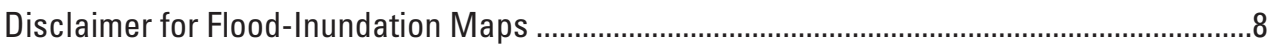

Uncertainties and Limitations for Use of Flood-Inundation Maps.......................................10

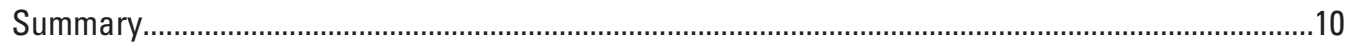

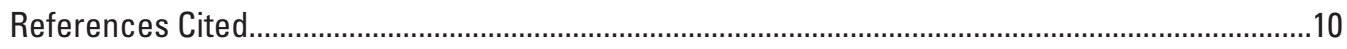

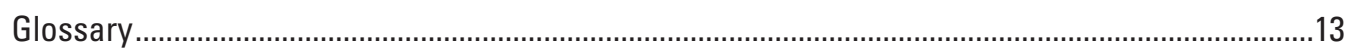

\section{Figures}

1. Map showing location of study reach for the Licking River at Falmouth, Kentucky, and location of U.S. Geological Survey (USGS) streamgages

2. Graph showing maps made for the scenario-based modeling approach for a given flood stage at Licking River at Catawba, Kentucky (U.S. Geological Survey [USGS] station 03253500) and at South Fork Licking River at Hayes, Kentucky (USGS station 03253000)

3. Graph showing comparison of hydraulic-model output and stage-discharge rating at Licking River at Catawba, Kentucky (U.S. Geological Survey station 03253500)

4. Graph showing comparison of hydraulic-model output and measured peak for a major flood event on March 3, 1997, at Licking River at Catawba, Kentucky (U.S. Geological Survey station 03253500).

5. Flood-inundation map for the Licking River at Catawba, Kentucky, (U.S. Geological Survey station 03253500) near Falmouth, corresponding to a stage of 58 feet, and at South Fork Licking River at Hayes, Kentucky (U.S. Geological Survey station 03253000 ), corresponding to a stage of 28 feet 


\section{Tables}

1. U.S. Geological Survey streamgage information for study basin, Licking River and South Fork Licking River, Kentucky.

2. South Fork Licking River flow ratio analysis by the U.S. Army Corps of Engineers...........5

3. Comparison of target water-surface elevations at USGS streamgage 03253500 , Licking River at Catawba, Kentucky, with water-surface elevations output from the hydraulic model.

4. Comparison of target water-surface elevations at USGS streamgage 03253000 , South Fork Licking River at Hayes, Kentucky, with water-surface elevations output from the hydraulic model.

5. Comparison of hydraulic-model water-surface elevation and the measured watersurface elevation for a major flood on March 3, 1997, Licking River, Kentucky..

6. Stages and water-surface elevations with corresponding estimated discharges at U.S. Geological Survey station 03253500, Licking River at Catawba, Kentucky, for selected simulated water-surface profiles

\section{Conversion Factors}

U.S. customary units to International System of Units

\begin{tabular}{lcl}
\hline \multicolumn{1}{c}{ Multiply } & By & To obtain \\
\hline & Length & \\
\hline foot $(\mathrm{ft})$ & 0.3048 & meter $(\mathrm{m})$ \\
mile $(\mathrm{mi})$ & 1.609 & kilometer $(\mathrm{km})$ \\
\hline & Area & \\
\hline square mile $\left(\mathrm{mi}^{2}\right)$ & 2.590 & square kilometer $\left(\mathrm{km}^{2}\right)$ \\
\hline & Flow rate & \\
\hline cubic foot per second $\left(\mathrm{ft}^{3} / \mathrm{s}\right)$ & 0.02832 & cubic meter per second $\left(\mathrm{m}^{3} / \mathrm{s}\right)$ \\
\hline & Hydraulic gradient & \\
\hline foot per mile $(\mathrm{ft} / \mathrm{mi})$ & 0.1894 & meter per kilometer $(\mathrm{m} / \mathrm{km})$ \\
\hline
\end{tabular}

Vertical coordinate information is referenced to the North American Vertical Datum of 1988 (NAVD 88).

Horizontal coordinate information is referenced to the North American Datum of 1983 (NAD 83). 


\title{
Flood-Inundation Map Library for the Licking River and South Fork Licking River near Falmouth, Kentucky
}

\author{
By Jeremiah G. Lant
}

\section{Abstract}

Digital flood inundation maps for a 17-mile reach of Licking River and 4-mile reach of South Fork Licking River near Falmouth, Kentucky, were created by the U.S. Geological Survey (USGS) in cooperation with Pendleton County and the U.S. Army Corps of Engineers-Louisville District. The inundation maps, which can be accessed through the USGS Flood Inundation Mapping Science Web site at http://wim.usgs.gov/ FIMI/FloodInundationMapper.html, depict estimates of the areal extent and depth of flooding corresponding to selected water levels (stages) at the USGS streamgage on the Licking River at Catawba, Ky., (station 03253500) and the USGS streamgage on the South Fork Licking River at Hayes, Ky., (station 03253000). Current conditions (2015) for the USGS streamgages may be obtained online at the USGS National Water Information System site (http://waterdata.usgs.gov/nwis). In addition, the streamgage information has been provided to the National Weather Service (NWS) for incorporation into their Advanced Hydrologic Prediction Service (AHPS) flood warning system (http:/water.weather.gov/ahps/). The flood hydrograph forecasts provided by the NWS are usually collocated with USGS streamgages. The forecasted peak-stage information, also available on the NWS Web site, may be used in conjunction with the maps developed in this study to show predicted areas of flood inundation.

In this study, flood profiles were computed for the Licking River reach and South Fork Licking River reach by using a one-dimensional step-backwater model. The hydraulic model was calibrated by using the most current (2015) stage-discharge relations for the Licking River at Catawba, Ky., and the South Fork Licking River at Hayes, Ky., USGS streamgages. The calibrated model was then used to calculate 60 water-surface profiles for a sequence of flood stages, at 2-foot intervals, referenced to the streamgage datum and ranging from an elevation near bankfull to the elevation associated with a major flood that occurred in the region in 1997. To delineate the flooded area at each interval flood stage, the simulated water-surface profiles were combined with a digital elevation model of the study area by using geographic information system software.
The availability of these flood inundation maps for Falmouth, Ky., along with online information regarding current stages from the USGS streamgages and forecasted stages from the NWS, provides emergency management personnel and local residents with information that is critical for flood response activities such as evacuations, road closures, and post-flood recovery efforts.

\section{Introduction}

Falmouth is a small city in Pendleton County, Kentucky, with an estimated population of 2,132 (U.S. Census Bureau, 2014). Falmouth is located at the confluence of the Licking River and South Fork Licking River. Falmouth's location and low-lying flood plains makes the city susceptible to flooding. According to the flood categories established by the National Weather Service (NWS; National Weather Service, 2015), the City of Falmouth has experienced approximately 22 floods since the early 1900s. Most notably on March 3, 1997 , the City of Falmouth experienced a major and catastrophic flooding event where the Licking River reached a stage of approximately 52 feet ( $\mathrm{ft} ; 24 \mathrm{ft}$ above the flood stage set by the NWS). Much of the city was under several feet of water, causing major property damage and four fatalities (Cincinnati Enquirer, 1997; New York Times, 1997).

Prior to this study, Falmouth officials relied on several information sources (all of which are available on the Internet) to make decisions on how to best alert the public and mitigate flood damages. Two sources are the 2011 URS Corporation hydraulics (URS Corporation, 2011a) and hydrology reports (URS Corporation, 2011b), which support the Federal Emergency Management Agency (FEMA) Flood Insurance Study (FIS) for Pendleton County and incorporated areas (Federal Emergency Management Agency, 2011). Additional sources of information consist of the USGS streamgage downstream from Falmouth: Licking River at Catawba, Ky., (station 03253500; http://waterdata.usgs.gov/nwis/uv?03253500) (U.S. Geological Survey, 2015a), from which current and historical water levels (stage) can be obtained, and two USGS streamgages upstream from Falmouth - South Fork Licking River at Hayes, Ky., (station 03253000; http://waterdata.usgs.gov/usa/nwis/ uv?03253000) (U.S. Geological Survey, 2015b) and Licking 
River at McKinneysburg, Ky., (station 03251500; http://waterdata.usgs.gov/ky/nwis/uv?site_no=03251500) (U.S. Geological Survey, 2015c). A third source is the NWS forecast of peak stage at the confluence of the Licking River and the South Fork Licking River in Falmouth, Ky., available through the Advanced Hydrologic Prediction Service (AHPS) Web site (NWS forecast point FLMK2; http://water.weather.gov/ahps2/ hydrograph.php?wfo=iln\&gage=FLMK2) (National Weather Service, 2015). The USGS streamgages within the study reach are equipped with satellite radio transmitters that allow data to be transmitted in near real time. Streamflow and stage data for a particular streamgage can be accessed online from the USGS at http://waterdata.usgs.gov/ky/nwis/current/?type=flow.

Although current USGS stage and NWS forecasted stage information is particularly useful for residents in the immediate vicinity of a streamgage, it is of limited use to residents farther upstream or downstream because the water-surface elevation is not constant along the entire stream channel. Additionally, knowledge of a water level at a streamgage is difficult to translate into depth and areal extent of flooding at points distant from the streamgage. One way to address these informational gaps is to produce a library of flood-inundation maps that are referenced to the stages recorded at the USGS streamgage. By referring to the appropriate map, emergency responders can discern the severity of flooding (depth of water and areal extent), identify roads that are or will soon be flooded, and make plans for notification or evacuation of residents in harm's way for some distance upstream and downstream from the streamgage. In addition, the capability to visualize the potential extent of flooding has been shown to motivate residents to take precautions and heed warnings that they might have previously disregarded.

\section{Purpose and Scope}

The purpose of this report is to (1) describe the development of a series of estimated flood-inundation maps for a 17-mile (mi) reach of the Licking River and a 4-mi reach of the South Fork Licking River near Falmouth, Ky., and (2) provide the City of Falmouth and the public with a library of flood-inundation maps that correspond to water levels referenced to the water-surface elevation and gage heights at the USGS streamgage at Licking River at Catawba, Ky., (station 03253500) and the USGS streamgage on the South Fork Licking River at Hayes, Ky. (station 03253000). The flood-inundation maps and other flood information are made available on the USGS Flood Inundation Mapping Science Web site at http://wim.usgs.gov/FIMI/FloodInundationMapper.html. Internet users can select inundation maps on the basis of projected gage heights that correspond to the current stages at the USGS streamgage, the NWS forecasted peak stage, or other desired stream stages.
The scope of the study includes a 17-mi reach of the Licking River from McKinneysburg, Ky., to Catawba, Ky., and a 4-mi reach of South Fork Licking River, approximately 4 mi south of Falmouth (fig. 1). To develop floodinundation maps, a hydraulic model of the two river reaches was developed to provide water-surface profiles for various flood stages.

This study was part of an effort conducted through the Silver Jackets Program (Silver Jackets, 2015). The Silver Jackets Program is a collaborative flood-mitigation effort made up of intergovernmental flood risk management teams for the purpose of maximizing available funds and capabilities from various government agencies to complete projects that help cities with hazard mitigation, emergency management, and flood-plain management. The Army Corps of Engineers Louisville District and the USGS worked together with the City of Falmouth to complete this study. As part of the agreement, the Army Corps of Engineers developed and calibrated the hydraulic model, and the USGS created the floodinundation maps and published the maps on the USGS Flood Inundation Mapping Science Web site at http://wim.usgs.gov/ FIMI/FloodInundationMapper.html.

\section{Study Area Description}

The Licking River is a tributary to the Ohio River. The headwaters originate in Magoffin County in southeast Kentucky, and the river flows generally northwestward for approximately 300 mi before entering the Ohio River. The South Fork Licking River is a tributary to the Licking River; the reach studied is near the confluence of the Licking River and South Fork Licking River. The drainage area of the Licking River at USGS station 03253500 is approximately 3,300 square miles (U.S. Geological Survey, 2015a). The drainage area of the South Fork Licking River at USGS station 03253000 is approximately 915 square miles (U.S. Geological Survey, 2015b). Except for the South Fork Licking River, no other major tributary joins the main stem Licking River as it flows through Falmouth. The basin terrain mainly consists of low-lying and flat areas with some rolling hills in the flood plains. The study reach on the Licking River is approximately $17 \mathrm{mi}$ long, has an average top-of-bank channel width of about $200 \mathrm{ft}$, and has an average channel slope of 1 foot per mile. The study reach on the South Fork Licking River is approximately $4 \mathrm{mi}$ long, has an average top-of-bank channel width of about $200 \mathrm{ft}$, and has an average channel slope of 5 feet per mile. The Licking River within the study reach has two major road crossings that lie within the channel or adjacent to the flood plain. The South Fork Licking River within the study reach has three major road crossings that lie within the channel or the adjacent flood plain. 


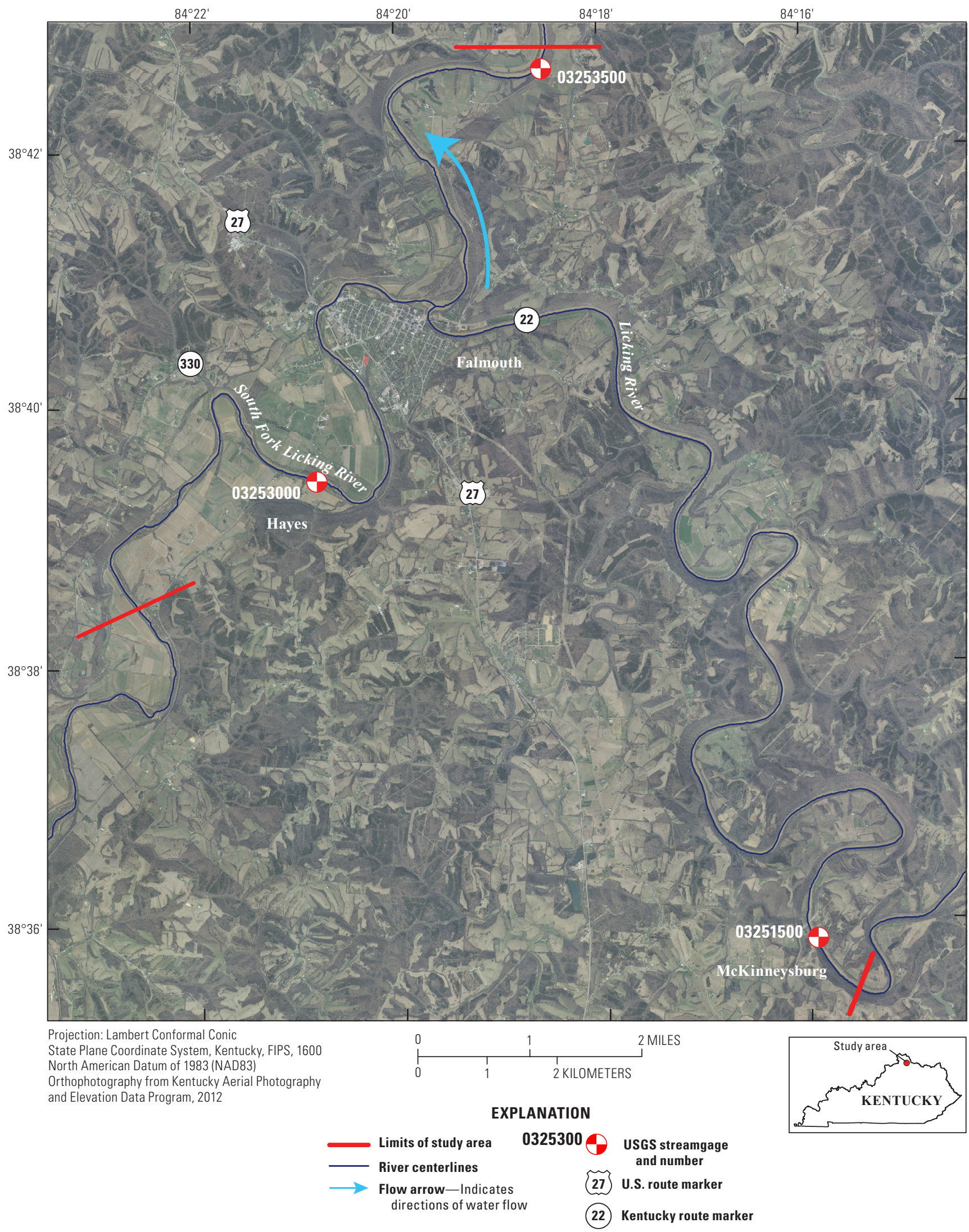

Figure 1. Map showing location of study reach for the Licking River at Falmouth, Kentucky, and location of U.S. Geological Survey (USGS) streamgages. 


\section{Previous Studies}

The FIS by FEMA is a compilation and presentation of flood risk within a community for the National Flood Insurance Program (Federal Emergency Management Agency, 2015). A FIS report is regulatory by nature and contains floodelevation data in flood profiles and data tables that are based on theoretical streamflows. The flood-inundation studies conducted by the USGS are nonregulatory by nature and contain detailed flood-elevation data in flood maps that are based on measured stages and (or) flows.

The current FIS for Pendleton County (Federal Emergency Management Agency, 2011) was completed by the URS Corporation in 2011 (URS Corporation, 2011a, b). The URS Corporation developed a hydrologic and hydraulic model in support of the FIS. The URS Corporation study provided information on water-surface profiles and associated floodplain maps for the Licking River at the 1.0- and 0.2-percent annual exceedance probabilities within the study area. The Kentucky Department of Environmental Protection Division of Water provided the hydraulic model used in the FIS.

\section{Constructing Water-Surface Profiles}

The following general steps were taken to construct the water-surface profiles: (1) examination of current and historical data from streamgages on the Licking River and South Fork Licking River (table 1); (2) collection of streamflow data; (3) collection of topographic data, geometric data (for structures/bridges), and bathymetric data throughout the study reach; (4) determination of energy-loss factors (roughness coefficients) in the stream channel and flood plain; (5) determination of boundary conditions for the hydraulic model; (6) development and calibration of the hydraulic model; and (7) computation of water-surface profiles by means of HEC-RAS, the U.S. Army Corps of Engineers' hydraulic modeling software (U.S. Army Corps of Engineers, 2010).

The modeling approach and objective for this study was to produce flood-inundation maps for a large range of watersurface profiles on the Licking River and South Fork Licking
River that covered a multitude of flooding scenarios. The City of Falmouth was most interested in knowing the manner in which different flood scenarios on the Licking River and the South Fork Licking River could occur, even if the scenarios had not previously occurred or were not previously measured. The modeling approach consisted of increasing the flow on the Licking River main stem while keeping the flow constant on the South Fork Licking River tributary and separately increasing the flow on the South Fork Licking River tributary while keeping the flow on the Licking River main stem constant. On the basis of this modeling approach, water-surface profiles were created for flood scenarios that could potentially occur. The modeling approach resulted in a total of 60 floodinundation maps (fig. 2).

The water-surface profiles used to produce the 60 floodinundation maps in this study were computed by using HEC-RAS, version 4.1.0 (U.S. Army Corps of Engineers, 2010). HEC-RAS simulates the flow of water through open channels and computes water-surface profiles. HEC-RAS is a one-dimensional, step-backwater model for simulation of water-surface profiles with steady-state (gradually varied) or unsteady-state flow computation options. The HEC-RAS analysis for this study was done by using the steady-state flow computation option because the global objective for this study was to develop a series of static inundation maps for various flood conditions.

Methods used are generally cited from previously published reports. If techniques varied significantly from previously documented methods because of local hydrologic conditions or available data, they are described in detail in this report. For the Licking River, maps were produced for water levels referenced to the water-surface elevation (stage) at station 03253500 and ranging from near bankfull $(30 \mathrm{ft}$; $529.298 \mathrm{ft}$ above the North American Vertical Datum of 1988 [NAVD 88]) to the elevation that exceeds that of the major flood event of 1997 (60 ft; $559.298 \mathrm{ft}$ above NAVD 88). For the South Fork Licking River, maps were produced for water levels referenced to the water-surface elevation (stage) at station 03253000 and ranging from near bankfull $(20 \mathrm{ft}$; $556.415 \mathrm{ft}$ above NAVD 88 ) to the elevation that exceeds that of the major flood event of 1997 ( $28 \mathrm{ft} ; 564.415 \mathrm{ft}$ above NAVD 88).

Table 1. U.S. Geological Survey streamgage information for study basin, Licking River and South Fork Licking River, Kentucky.

[mi², square miles; ft, feet; NAVD 88, North American Vertical Datum of 1988]

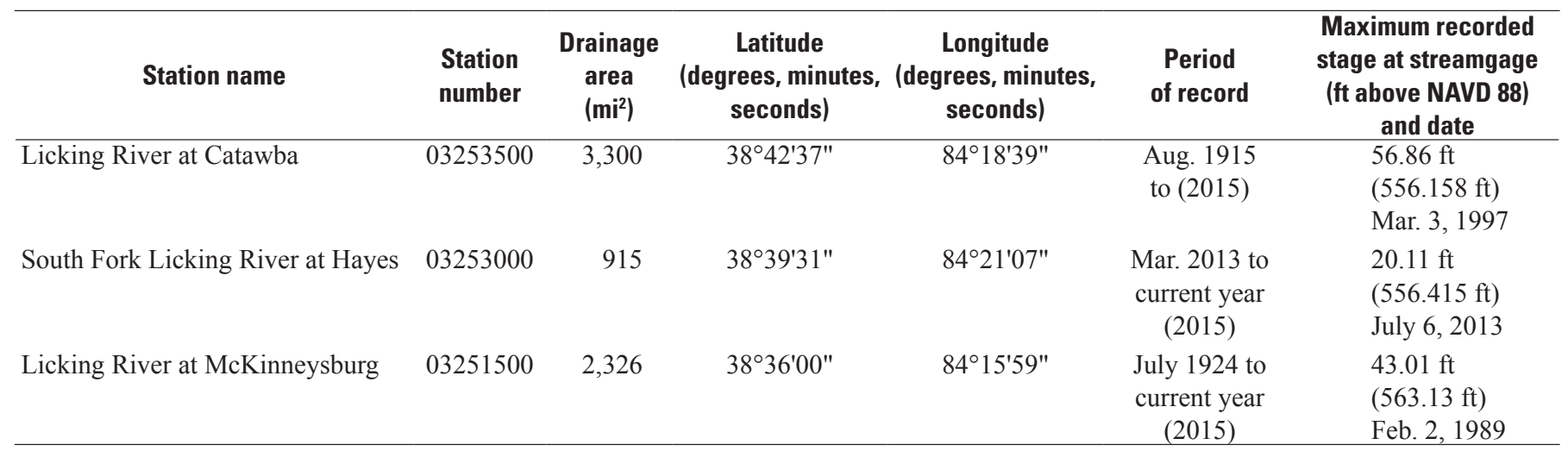




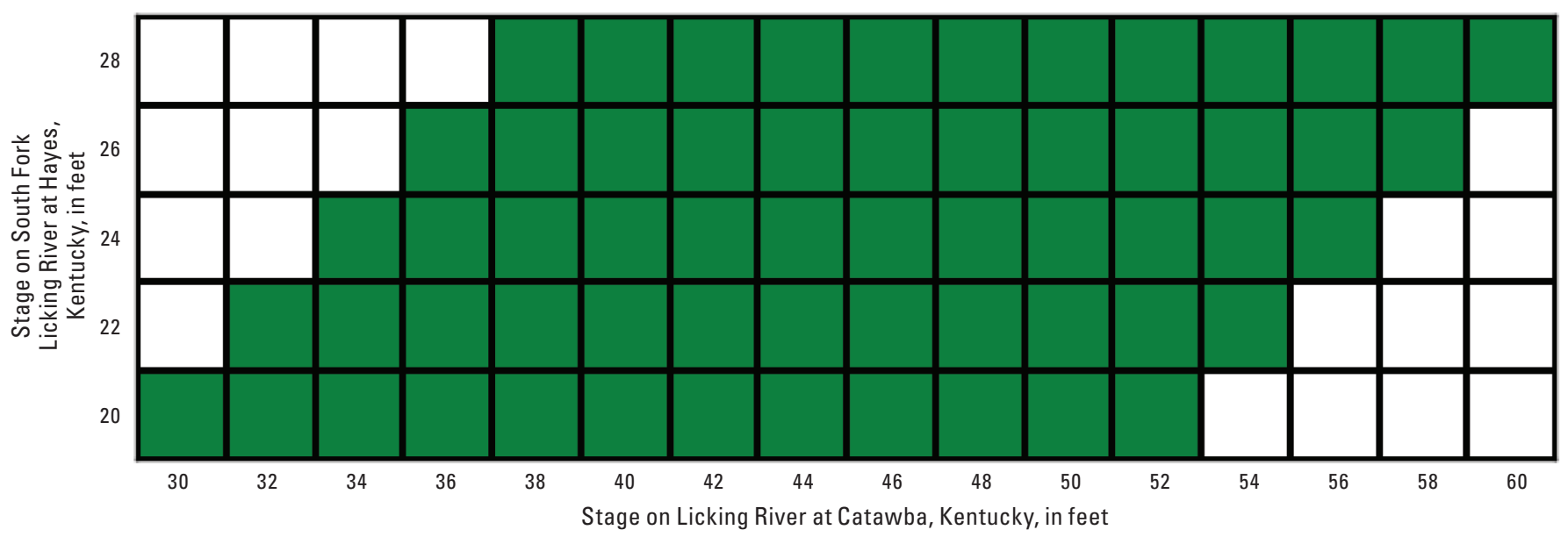

Figure 2. Maps made for the scenario-based modeling approach for a given flood stage at Licking River at Catawba, Kentucky (U.S. Geological Survey [USGS] station 03253500) and at South Fork Licking River at Hayes, Kentucky (USGS station 03253000). Green squares indicate map was made. White squares indicate no map was made.

\section{Hydrologic and Steady-Flow Data}

The study-area hydrologic network consists of three USGS streamgages (fig. 1; table 1). The streamgages on the Licking River at Catawba, Ky., (station no. 03253500) and at McKinneysburg, Ky., (station 03251500) have continuous records of measured stage (water level; table 1) and computed streamflow. The streamgage on the South Fork Licking River at Hayes, Ky., (station 03253000) has continuous records of measured stage (water level; table 1) and computed streamflow since March 2013. All measured stages and corresponding watersurface elevations in this study are referenced to NAVD 88.

Steady-flow data necessary for the hydraulic model consisted of flow regime, downstream boundary conditions (known water-surface elevation associated with a measurement, critical depth, normal depth, or streamgage rating-curve value), and peak-discharge information. The hydraulic model contains a rating curve boundary condition developed from flood-frequency simulations of the lower Licking River in the URS hydraulic model. Other hydrologic data for the study reach were obtained from previous studies and field measurements of streamflow made at stations 03253500 and 03253000 , and the most current (2015) stage-discharge relations at station 03253500. Associated discharges for the Licking River reach from McKinneysburg, Ky., to Falmouth, Ky., were based on the ratio of streamflows from the URS model. Annual exceedance probabilities in the URS model were based on USGS Bulletin 17B (U.S. Geological Survey, 1982) analyses for the streamgages on the Licking River at Catawba, Ky., (station 03253500) and at McKinneysburg, Ky. (station no. 03251500). Associated discharges for streamgage South Fork Licking River at Hayes, Ky., (station 03253000) were based on the ratios of streamflows from the streamgage on the Licking River at Catawba, Ky., (station 03253500) calculated by the U.S. Army Corps of Engineers (table 2). For the short shared period of record for this study (March 2013-March 2015), the flow ratios were variable across the range of streamflows at station 03253000, and the South Fork Licking River streamflow exceeded 20,000 cubic feet per second during only one event (2013). On the basis of the flow ratios and streamflow, a best estimate average flow ratio of 0.44 percent was used for all streamflows at station 03253000 .

\section{Topographic and Bathymetric Data}

Light detection and ranging (lidar) data for an area near Falmouth were furnished by the Kentucky Energy and Environment Cabinet (Carey Johnson, Kentucky Energy and Environment Cabinet, written commun., 2012). Lidar provides high-resolution topographic data for models and other applications. The lidar data used in the study have a horizontal resolution of $5.0 \mathrm{ft}$ and a vertical accuracy of $0.229 \mathrm{ft}$. The lidar data were collected and postprocessed by Photo Science, Inc., (Lexington, Ky.) in 2012, resulting in a series of tiled bare-earth digital elevation models (DEMs). The DEM tiles that cover the study area were mosaicked using geoprocessing tools in ArcGIS (Esri, 2015).

River bathymetric data within the study area were collected by USGS personnel (Albert Ruby, USGS, written commun., 2013). A 210-kilohertz Airmar ${ }^{\mathrm{TM}}$ transducer and a

Table 2. South Fork Licking River flow ratio analysis by the U.S. Army Corps of Engineers.

[ $\mathrm{ft}^{3} / \mathrm{s}$, cubic feet per second; >, greater than]

\begin{tabular}{cc}
\hline $\begin{array}{c}\text { South Fork Licking River } \\
\text { streamflow } \\
\left(\mathbf{f t}^{3} / \mathbf{s}\right)\end{array}$ & $\begin{array}{c}\text { Average flow ratio } \\
\text { (South Fork Licking River } \\
\text { to Licking River) }\end{array}$ \\
$>2,000$ & 0.37 \\
$>5,000$ & 0.43 \\
$>10,000$ & 0.44 \\
$>20,000$ & 0.58 \\
\hline
\end{tabular}


Reson Navisound ${ }^{\mathrm{TM}} 210$ echo sounder were used to collect the bathymetric data. A Trimble ${ }^{\mathrm{TM}}$ Differential Global Positioning System (DGPS) was used for horizontal positioning during the survey. The HYPACK ${ }^{\mathrm{TM}}$ navigation software package was used to integrate riverbed depths along with the DGPS horizontal position data and to display the location of the boat on a georeferenced aerial photo of the river for navigation. The bathymetric data were collected in a series of cross sections for most of the Licking River reach within the study area and all of the South Fork Licking River reach within the study area.

Two hydraulic structures are present within the study area on the Licking River, and three hydraulic structures are present within the study area on the South Fork Licking River. All five structures were included in the hydraulic model. The structure datasets for the study area on the Licking River originated from the URS study, and the structure datasets for the South Fork Licking River were obtained from cursory surveys. The structure datasets were checked and validated in consultation with the City of Falmouth (Mike Moore, City of Falmouth at the Office of Emergency Management, written commun., 2015) to ensure that no newly built structures were within the study area.

HEC-GeoRAS and ArcGIS were used to extract floodplain elevations from the lidar-derived DEM at selected cross sections along the Licking River and South Fork Licking River for use in the HEC-RAS model. The HEC-RAS model included cross sections from the river bathymetric data within the study area. The flood-plain and river-bathymetry elevations were merged with the structure datasets during the development of the HEC-RAS model.

\section{Energy-Loss Factors}

The URS study was used to select initial (precalibration) channel and flood-plain friction coefficients. These friction coefficients, commonly called Manning's roughness coefficients or Manning's $n$ values, account for energy (friction) loss in model calculations. The final Manning's $n$ values used ranged from 0.052 to 0.057 for the Licking River channel and 0.07 to 0.1 for the overbank areas. The final Manning's $n$ values used were 0.047 for the South Fork Licking River channel and 0.06 to 0.1 for the overbank areas; these values were selected according to the channel and flood-plain characteristics described by Chow (1959). Both river channels are meandering with heavy weeds and stones and have sluggish reaches with some deep pools. The riverbanks and overbank areas throughout the study area domain are highly vegetated. The URS study was also used in the building of the ineffective flow areas in the hydraulic model. Ineffective flow areas are areas or portions of a cross section where the water velocity is near zero, which can result in ponding. The ineffective flow areas were initially developed from the URS study and were adjusted while refining the model.

\section{Model Calibration and Performance}

The hydraulic model for this study, built by the Army Corps of Engineers-Louisville District, was calibrated to the most current stage-discharge relation at station 03253500 (USGS rating no. 19) and to the most current stage-discharge relation at station 03253000 (USGS rating no. 1). Model calibration was accomplished by adjusting Manning's $n$ values until the results of the hydraulic computations closely agreed with the known flood-discharge and stage values (within $+/-0.50 \mathrm{ft}$ ); Manning's $n$ values were also verified as falling within realistic bounds, as described by Chow (1959). Owing to the wide range of discharges on the Licking River and South Fork Licking River, flow roughness factors-roughness factors that vary on the basis of the amount of streamflowwere also used to calibrate the hydraulic model. The flow roughness factors ranged from 0.58 to 1.05 . Differences between measured and simulated water-surface elevations for specified streamflows from the established stage-discharge relation were within $0.16 \mathrm{ft}$ (table 3; fig. 3; at station 03253500 (Licking River). Differences between measured and simulated water levels for specified streamflows from the established stage-discharge relation were within $0.08 \mathrm{ft}$ (table 4) at station 03253000 (South Fork Licking River). These calibration results demonstrate that the model is capable of simulating accurate water levels over a wide range of streamflows in the basin. The hydraulic model was also validated to a recent major flood event that occurred in Falmouth, Ky., in 1997. The difference between the model water-surface elevation and the rating elevation (measured peak) at station 03253500 was $0.82 \mathrm{ft}$ (table 5; fig. 4).

Table 3. Comparison of target water-surface elevations at USGS streamgage 03253500, Licking River at Catawba, Kentucky, with water-surface elevations output from the hydraulic model.

[ft, feet; NAVD 88, North American Vertical Datum of 1988]

\begin{tabular}{cccc}
\hline $\begin{array}{c}\text { Stage } \\
\text { (ft NAVD 88) }\end{array}$ & $\begin{array}{c}\text { Target } \\
\text { water-surface } \\
\text { elevation } \\
\text { (ft NAVD 88) }\end{array}$ & $\begin{array}{c}\text { Model } \\
\text { water-surface } \\
\text { elevation } \\
\text { (ft NAVD 88) }\end{array}$ & $\begin{array}{c}\text { Elevation } \\
\text { difference } \\
\text { (model-rating) } \\
\text { (ft NAVD 88) }\end{array}$ \\
\hline 20.0 & 519.26 & 519.19 & -0.07 \\
24.0 & 523.27 & 523.25 & -0.02 \\
28.0 & 527.29 & 527.24 & -0.05 \\
32.0 & 531.25 & 531.19 & -0.06 \\
36.0 & 535.28 & 535.29 & 0.01 \\
40.0 & 539.30 & 539.24 & -0.06 \\
42.0 & 541.30 & 541.16 & -0.14 \\
44.0 & 543.30 & 543.20 & -0.10 \\
46.0 & 545.30 & 545.22 & -0.08 \\
48.0 & 547.30 & 547.24 & -0.06 \\
50.0 & 549.30 & 549.20 & -0.10 \\
52.0 & 551.30 & 551.16 & -0.14 \\
54.0 & 553.30 & 553.29 & -0.01 \\
56.0 & 555.30 & 555.33 & 0.03 \\
58.0 & 557.30 & 557.30 & 0.00 \\
60.0 & 559.30 & 559.14 & -0.16 \\
\hline
\end{tabular}




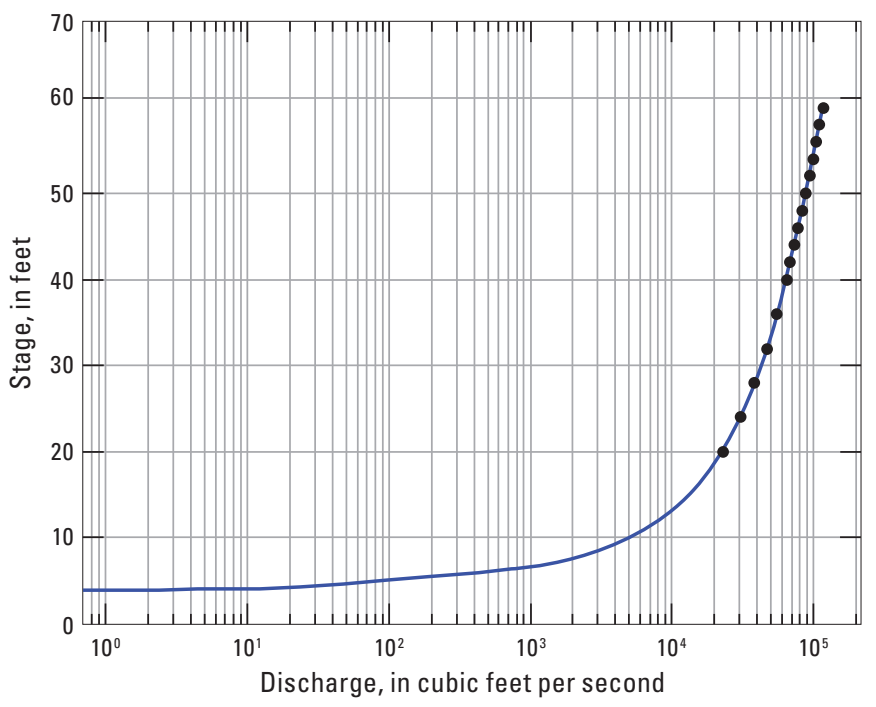

EXPLANATION

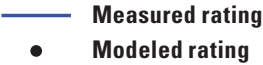

Figure 3. Comparison of hydraulic-model output and stage-discharge rating at Licking River at Catawba, Kentucky (U.S. Geological Survey station 03253500).

\section{Development of Water-Surface Profiles}

Profiles were developed for 60 combinations of river stages (fig. 2) at 2-ft intervals between $30 \mathrm{ft}$ and $60 \mathrm{ft}$ as referenced to the streamgage on the Licking River at Catawba, Ky., (station 03253500) and between $20 \mathrm{ft}$ and $28 \mathrm{ft}$ as referenced to the streamgage on the South Fork Licking River at Hayes, Ky. (station 03253000). Discharges corresponding to the various stages were obtained from the most current stagedischarge relations (2015) at stations 03253500 and 03253000.

Discharges for all profiles (table 6) were selected with the assumption that within the 17-mi study reach on the Licking River, there are no significant inflows, except for the South Fork Licking River. The discharges were estimated to be uniform and steady throughout the study reach.

\section{Inundation Mapping}

Flood-inundation maps were created for two river reaches near Falmouth, Ky., referenced to USGS streamgage site, station 03253500 (Licking River at Catawba, Ky.). The inundation maps were created in ArcGIS, a geographic information system, by combining the water-surface profiles from the hydraulic model and DEM data. The DEM data were derived from 5.0-ft horizontal-resolution lidar data with a vertical accuracy of $0.229 \mathrm{ft}$, obtained from the Kentucky Division of Water. Estimated flood-inundation datasets for each simulated water-surface profile were developed with HEC-GeoRAS software (U.S. Army Corps of Engineers, 2009). HEC-GeoRAS is a set of procedures, tools, and utilities for processing geospatial data in ArcGIS by use of a graphical user interface. The interface allows the preparation of geometric data for import into HEC-RAS and processes simulation results exported from HEC-RAS (U.S. Army Corps of Engineers, 2010). The datasets produced by using HEC-GeoRAS included floodinundation polygons and water depth grids. The procedure used to create the datasets for each simulated water-surface profile included creating a bounding polygon that defined the analysis extent for mapping the inundation. Then, surfaces containing the water-surface elevation for each simulated water-surface profile were created within the analysis extent. Lastly, the DEM was subtracted from each surface containing the water-surface elevation for each simulated water-surface profile, resulting in the final water depth grids. The final water depth grids are accurate in the flood-plain areas where flooding is of most concern, but not within the river channel, because the river channel surface on the DEM was not edited with an interpolated surface between the cross sections collected during the bathymetric survey. The water depth grids were then converted to the final flood-inundation polygons representing the inundation extent. The HEC-GeoRAS results were modified to ensure

Table 4. Comparison of target water-surface elevations at USGS streamgage 03253000 , South Fork Licking River at Hayes, Kentucky, with water-surface elevations output from the hydraulic model.

[ft, feet; NAVD 88, North American Vertical Datum of 1988]

\begin{tabular}{cccc}
\hline $\begin{array}{c}\text { Stage } \\
\text { (ft NAVD 88) }\end{array}$ & $\begin{array}{c}\text { Target } \\
\text { water-surface } \\
\text { elevation } \\
\text { (ft NAVD 88) }\end{array}$ & $\begin{array}{c}\text { Model } \\
\text { water-surface } \\
\text { elevation } \\
\text { (ft NAVD 88) }\end{array}$ & $\begin{array}{c}\text { Elevation } \\
\text { difference } \\
\text { (model-rating) } \\
\text { (ft NAVD 88) }\end{array}$ \\
\hline 11.8 & 548.18 & 548.17 & -0.01 \\
13.5 & 549.92 & 549.97 & 0.05 \\
15.3 & 551.68 & 551.76 & 0.08 \\
17.0 & 553.38 & 553.41 & 0.03 \\
18.6 & 555.04 & 555.07 & 0.03 \\
20.2 & 556.65 & 556.67 & 0.02 \\
21.0 & 557.45 & 557.44 & -0.01 \\
21.8 & 558.26 & 558.25 & -0.01 \\
22.6 & 559.02 & 559.00 & -0.02 \\
23.4 & 559.79 & 559.78 & -0.01 \\
24.1 & 560.53 & 560.53 & 0.00 \\
\hline
\end{tabular}

Table 5. Comparison of hydraulic-model water-surface elevation and the measured water-surface elevation for a major flood on March 3, 1997, Licking River, Kentucky.

[ $\mathrm{ft}^{3} / \mathrm{s}$, cubic feet per second; ft, feet; gage datum: $499.298 \mathrm{ft}$, North American Vertical Datum of 1988 (NAVD 88)]

\begin{tabular}{cccc}
\hline $\begin{array}{c}\text { Discharge } \\
\left(\mathbf{f t}^{3} / \mathbf{s}\right)\end{array}$ & $\begin{array}{c}\text { Measured } \\
\text { water-surface } \\
\text { elevation } \\
\text { (ft NAVD 88) }\end{array}$ & $\begin{array}{c}\text { Model } \\
\text { water-surface } \\
\text { elevation } \\
\text { (ft NAVD 88) }\end{array}$ & $\begin{array}{c}\text { Elevation } \\
\text { difference } \\
\text { (model-rating) } \\
\text { (ft NAVD 88) }\end{array}$ \\
\hline 110,000 & 556.16 & 556.98 & 0.82 \\
\hline
\end{tabular}




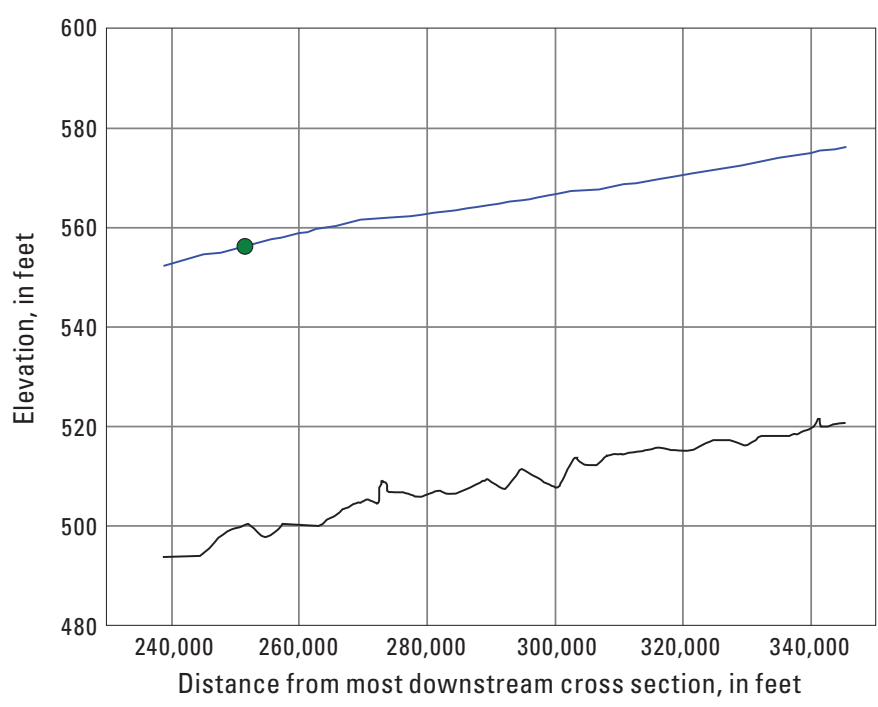

EXPLANATION

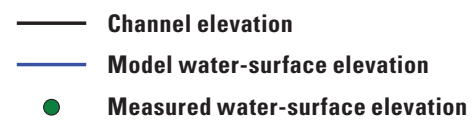

Figure 4. Comparison of hydraulic-model output and measured peak for a major flood event on March 3, 1997, at Licking River at Catawba, Kentucky (U.S. Geological Survey station 03253500).

a hydraulically reasonable transition of the boundary between modeled cross sections relative to the contour data for the land surface. The resulting inundation maps have a vertical accuracy of about $2.0 \mathrm{ft}$. The maps show estimated flood-inundated areas overlaid on high-resolution, georeferenced aerial photographs of the study area for each water-surface profile generated by the hydraulic model (fig. 5).

\section{Flood-Inundation Map Delivery}

The flood-inundation maps from this study depict estimates of the areal extent and depth of flooding corresponding to selected water levels (stages) at USGS streamgage 03253500, Licking River at Catawba, Kentucky. The study documentation is available online at the U.S. Geological
Survey Publications Warehouse (https://pubs.er.usgs.gov/ publication/sir/20165108). Also, a Flood Inundation Mapping Science Web site has been established to provide a portal at http://water.usgs.gov/osw/flood_inundation/ that the public can use to access USGS flood inundation study information. That Web portal has a link (http://wim.usgs.gov/FIMI/ FloodInundationMapper.html) to interactive online map libraries and provides detailed information on flood extent and depths for selected sites. The mapping application enables the production of customized flood-inundation maps from the map library for the Licking River and South Fork Licking River near Falmouth, KY. A link on the map library Web site connects to the USGS National Water Information System (U.S. Geological Survey, 2015a), which presents current stage and streamflow at USGS station 03253500, to which the inundation maps are referenced. The estimated flood-inundation maps are displayed in sufficient detail to note the extent of flooding with respect to individual structures so that preparations for flooding and decisions for emergency response can be performed efficiently. Roadways and bridges were closely reviewed and are shown as shaded (inundated and likely impassable) or not shaded (dry and passable) to facilitate emergency planning and use. The policy set forth by the NWS is that a bridge is considered to be inundated when the watersurface elevation exceeds the low chord ("low steel," or low member) of the bridge (National Oceanic and Atmospheric Administration, 2011). However, shaded buildings do not reflect inundation but denote that bare-earth surfaces in the vicinity of the buildings are inundated. When the water depth (as indicated in the Web mapping application by holding the cursor over an inundated area) in the vicinity of the building of interest exceeds that building's height, the structure can be considered fully submerged.

\section{Disclaimer for Flood-Inundation Maps}

Inundated areas shown should not be used for navigation, regulatory, permitting, or other legal purposes. The USGS provides these maps "as-is" for a quick reference, emergency planning tool but assumes no legal liability or responsibility resulting from the use of this information.

Table 6. Stages and water-surface elevations with corresponding estimated discharges at U.S. Geological Survey station 03253500, Licking River at Catawba, Kentucky, for selected simulated water-surface profiles.

[NAVD 88, North American Vertical Datum of 1988]

\begin{tabular}{|c|c|c|c|c|c|c|c|c|}
\hline \multirow[b]{2}{*}{ Stage (elevation) } & \multicolumn{8}{|c|}{$\begin{array}{l}\text { Stage, in feet above gage datum (water-surface elevation, in feet, NAVD 88) } \\
\text { associated with the indicated discharge value, } \\
\text { in cubic feet per second }\end{array}$} \\
\hline & $\begin{array}{c}30.00 \\
(529.298)\end{array}$ & $\begin{array}{c}32.00 \\
(531.298)\end{array}$ & $\begin{array}{c}34.00 \\
(533.298)\end{array}$ & $\begin{array}{c}36.00 \\
(535.298)\end{array}$ & $\begin{array}{c}38.00 \\
(537.298)\end{array}$ & $\begin{array}{c}40.00 \\
(539.298)\end{array}$ & $\begin{array}{c}42.00 \\
(541.298)\end{array}$ & $\begin{array}{c}44.00 \\
(543.298)\end{array}$ \\
\hline Estimated discharge & 42,400 & 46,600 & 51,000 & 55,400 & 59,900 & 64,500 & 69,100 & 73,800 \\
\hline Stage (elevation) & $\begin{array}{c}46.00 \\
(545.298)\end{array}$ & $\begin{array}{c}48.00 \\
(547.298)\end{array}$ & $\begin{array}{c}50.00 \\
(549.298)\end{array}$ & $\begin{array}{c}52.00 \\
(551.298)\end{array}$ & $\begin{array}{c}54.00 \\
(553.298)\end{array}$ & $\begin{array}{c}56.00 \\
(555.298)\end{array}$ & $\begin{array}{c}58.00 \\
(557.298)\end{array}$ & $\begin{array}{c}60.00 \\
(559.298)\end{array}$ \\
\hline
\end{tabular}




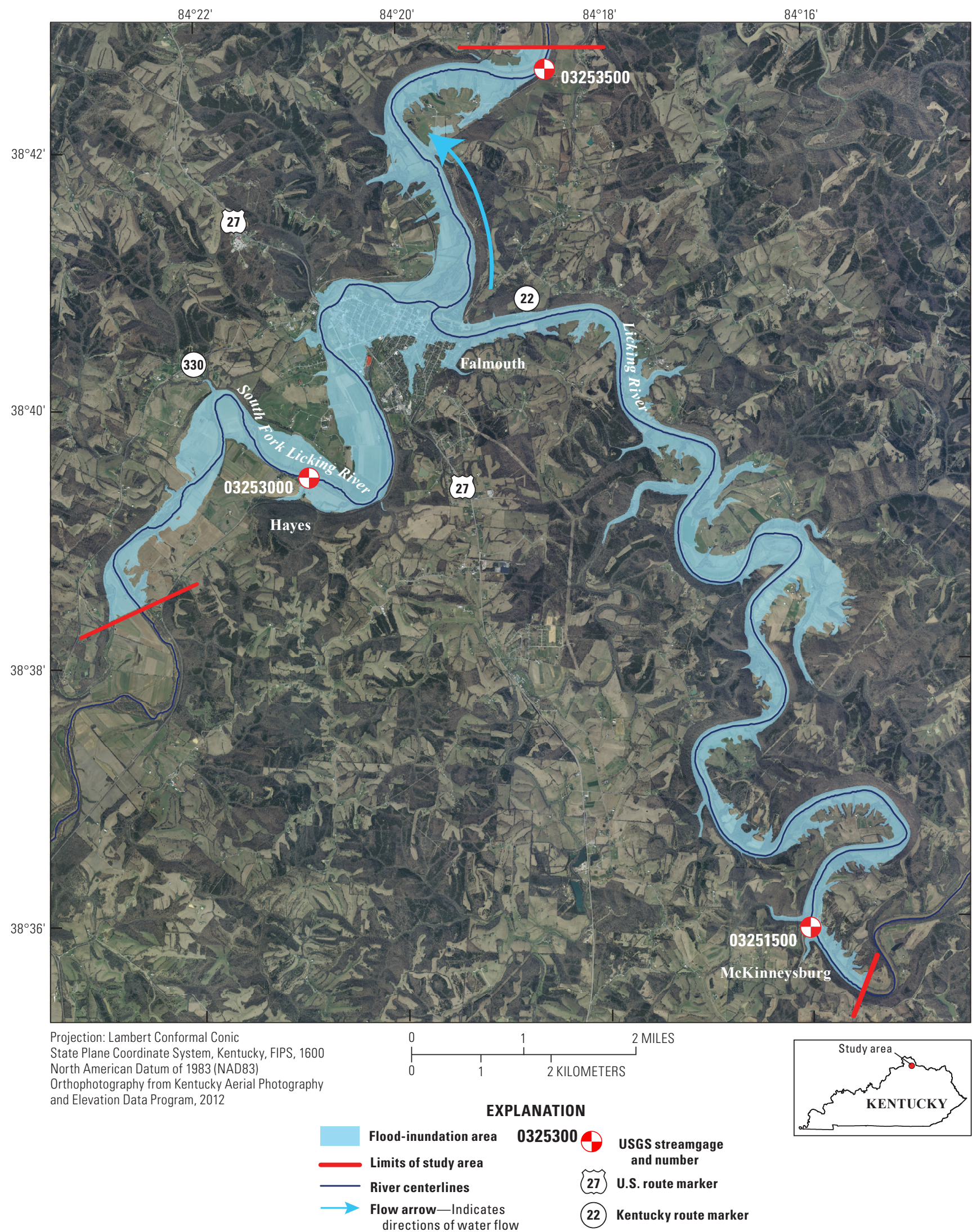

Figure 5. Flood-inundation map for the Licking River at Catawba, Kentucky, (U.S. Geological Survey station 03253500) near Falmouth, corresponding to a stage of 58 feet, and at South Fork Licking River at Hayes, Kentucky, (U.S. Geological Survey station 03253000), corresponding to a stage of 28 feet. 


\section{Uncertainties and Limitations for Use of Flood-Inundation Maps}

Although the flood-inundation maps represent the boundaries of inundated areas with a distinct line, some uncertainty is associated with these maps (Bales and Wagner, 2009).

The flood boundaries shown were estimated on the basis of stages (water-surface elevations) and streamflows at selected USGS streamgages. Water-surface elevations along the stream reaches were estimated by steady-state hydraulic modeling, assuming unobstructed flow, and using streamflows and hydrologic conditions anticipated at the USGS streamgage. The ratios of streamflows at the streamgage on the Licking River at Catawba, Ky., (station 03253500) to streamflows at the South Fork Licking River at Hayes, Ky., (station 03253000) used for model calibration were estimated to be 0.44 on the basis of the data available. The scenario-based modeling approach results in many potential flooding scenarios that have not previously occurred or have not been previously measured. The hydraulic model reflects the land-cover characteristics and any bridge, dam, levee, or other hydraulic structures existing as of June 2015. Unique meteorological factors (timing and distribution of precipitation) may cause actual streamflows along the modeled reach to vary from those assumed during a flood, which may lead to deviations in the water-surface elevations and inundation boundaries shown. Additional areas may be flooded due to unanticipated conditions such as changes in the streambed elevation or roughness, backwater into small tributaries along the study reach, or backwater from localized debris or ice jams. The accuracy of the floodwater extent portrayed on these maps will vary with the accuracy of the DEMs used to simulate the land surface.

If this series of flood-inundation maps will be used in conjunction with NWS river forecasts, the user should be aware of additional uncertainties that may be inherent or factored into NWS forecast procedures. The NWS uses forecast models to estimate the quantity and timing of water flowing through selected stream reaches in the United States. These forecast models (1) estimate the amount of runoff generated by precipitation and snowmelt, (2) simulate the movement of floodwater as it proceeds downstream, and (3) predict the flow and stage (water-surface elevation) for the stream at a given location (AHPS forecast point) throughout the forecast period (every 6 hours and 3 to 5 days out in many locations). For more information on AHPS forecasts, please see http://water.weather.gov/ahps/pcpn_and_river_forecasting.pdf. Additional uncertainties and limitations pertinent to this study may be described elsewhere in this report.

\section{Summary}

A library of 60 flood-inundation maps was developed in cooperation with Pendleton County and the U.S. Army Corps of Engineers-Louisville District for Licking River and South Fork Licking River near Falmouth, Kentucky. These maps, available through a USGS Web portal, in conjunction with the near real-time stage data from the U.S. Geological Survey streamgage 03253500 (Licking River at Catawba, Ky.) and National Weather Service flood-stage forecasts, will help to guide the general public in taking individual safety precautions and will provide city officials with a tool to efficiently manage emergency flood operations and flood mitigation efforts.

The maps were developed by using the U.S. Army Corps of Engineers' HEC-RAS and HEC-GeoRAS programs to compute water-surface profiles and to delineate estimated floodinundation areas for selected stream stages. The maps show estimated flood-inundation areas overlaid on high-resolution, georeferenced aerial photographs of the study area for stream stages between 30 feet (ft) and $60 \mathrm{ft}$ at station 03253500 and between $20 \mathrm{ft}$ and $28 \mathrm{ft}$ at station 03253000 . The maps are available at the USGS Flood Inundation Mapping Science Web site at http://wim.usgs.gov/FIMI/FloodInundationMapper.html, where users can interact with the maps and gain a general indication of depth of water at any point.

\section{References Cited}

Bales, J.D., and Wagner, C.R., 2009, Sources of uncertainty in flood inundation maps: Journal of Flood Risk Management, v. 2, no. 2, p. 139-147.

Chow, V.T., 1959, Open-channel hydraulics: New York, McGraw-Hill, 680 p.

Cincinnati Enquirer, 1997, Rivers unleashed, accessed August 2015 at http://www.enquirer.com/flood_of_97/.

Esri, 2015, ArcGIS, accessed May 2015 at http://www.esri.com/ software/arcgis/.

Federal Emergency Management Agency, 2011, Flood insurance study for Pendleton County, Kentucky: Washington D.C., Flood Insurance Study 21073CV000B.

Federal Emergency Management Agency, 2015, Flood insurance study Web page, accessed August 18, 2015, at http://www.fema.gov/floodplain-management/floodinsurance-study.

National Weather Service, 2015, Advanced Hydrologic Prediction Service, Licking River at Falmouth, Kentucky (FLMK2), accessed July 2015 at http://water.weather.gov/ ahps2/hydrograph.php?wfo=iln\&gage=FLMK2 . 
New York Times, 1997, Residents of flooded town put lives in shopping bags, accessed August 2015 at http://www. nytimes.com/1997/03/09/us/residents-of-flooded-town-putlives-in-shopping-bags.html?pagewanted=1 .

National Oceanic and Atmospheric Administration, 2011, NOAA partnered guidelines for the development of Advanced Hydrologic Prediction Service flood inundation mapping, accessed August 2015 at http://water.weather.gov/ ahps/NOAA_AHPS_Guidelines_Final_2011_v3.pdf.

Silver Jackets, 2015, Intergovernmental hazard risk management, accessed August 18, 2015, at http://silverjackets.nfrmp.us/ Home/About-The-Silver-Jackets-Program.

URS Corporation, 2011a, Hydraulics report for Licking River Bracken/Pendleton Counties, KY: MAS Cooperative Agreement EMA-2009-CA-5931, p. 1-10.

URS Corporation, 2011b, Hydrology report for Licking River Bracken/Pendleton Counties, KY: MAS Cooperative Agreement EMA-2009-CA-5931, p. 1-33.

U.S. Army Corps of Engineers, Hydrologic Engineering Center, 2009, HEC-GeoRAS, GIS tools for support of HEC-RAS using ArcGIS-User's manual, version 4.2 [variously paged].
U.S. Army Corps of Engineers, Hydrologic Engineering Center, 2010, HEC-RAS river analysis system-Hydraulic Reference Manual, version 4.1 [variously paged].

U.S. Census Bureau, 2014, 2014 Census interactive population search, Falmouth, KY, accessed August 2015 at http://www. census.gov/search-results.html?q=falmouth $\% 2 \mathrm{C}+$ ky\&search. $\mathrm{x}=0$ \&search. $\mathrm{y}=0$ \&search $=$ submit\&page $=1$ \&stateGeo $=$ none \& searchtype $=$ web.

U.S. Geological Survey, 1982, Flood flow frequency, Bulletin \#17B of the Hydrology Subcommittee, http://water.usgs.gov/ osw/bulletin17b/dl_flow.pdf.

U.S. Geological Survey, 2015a, National Water Information System for USGS 03253500 Licking River at Catawba, KY, $\mathrm{http}: / /$ waterdata.usgs.gov/nwis/inventory/?site_no $=03253500$.

U.S. Geological Survey, 2015b, National Water Information System for USGS 03253000 South Fork Licking River at Hayes, KY, http://waterdata.usgs.gov/nwis/inventory/?site no $=03253000$.

U.S. Geological Survey, 2015c, National Water Information System for USGS 03251500 Licking River at McKinneysburg, KY, http://waterdata.usgs.gov/ky/nwis/uv?site no $=03251500$. 



\section{Glossary}

\section{A}

Annual exceedance probability The probability that a flood of a particular size or greater will occur in any given year. As an example, a 1-percent annual exceedance probability flood has a 1-percent chance of being equaled or exceeded in any single year. A 1-percent annual exceedance probability flood is also referred to as a "100-year flood."

\section{D}

DEM Digital elevation model (DEM), a digital file consisting of terrain elevations for ground positions at regularly spaced horizontal intervals.

Depth grid A digital file consisting of the mathematical difference between the waterelevation surface and ground-elevation surface for ground positions at regularly spaced horizontal intervals.

\section{G}

Gage height Term used by the U.S. Geological Survey National Water Information System display to describe the height of water above the datum at a streamgage. It is synonymous with stage.

\section{I}

Inundation areas Surface representing areas covered by water, derived as the mathematical difference between the waterelevation surface and ground-elevation surface.

$\mathbf{R}$

Rating curve The relation between stage and discharge at a cross section in a river.

S

Stage Term used by the National Weather Service to describe the height of water above the datum at a streamgage. It is synonymous with gage height.

\section{W}

Water-surface elevation Elevation of water determined by adding the gage height of the water to the datum for the streamgage.

Water-surface profile A diagram showing how the elevation of a river changes along its centerline. 

Publishing support provided by the Denver Publishing Service Center

For more information concerning this publication, contact: Director, USGS Indiana-Kentucky Water Science Center 9818 Bluegrass Parkway

Louisville, KY 40299

(502) 493-1900

Or visit the Indiana-Kentucky Water Science Center Web site at http://ky.water.usgs.gov/

This publication is available online at http://dx.doi.org/10.3133/sir20165108 

